\title{
SKETSA GLOCAL THEOLOGY
}

\author{
Manase Gulo \\ Sekolah Tinggi Teologi Arastamar Bengkulu \\ manasegulo@sttab.ac.id
}

\begin{abstract}
Local theology is a model of theology that existed in postmodernism that emphasized the theology of the local cultural context. It means emphasize the efforts to meet church traditions and Christian themes with the reality of the life of the people around them. Simple theology always understands local sources which consist of local rituals, everyday language, folk songs, proverbs and art buildings. By using these elements means a theologian theologically contextually. The theologian was present and lived with people and listened to their voices. In this case, the simple theology seeks to respect and use the wisdom that is in the local culture, so that local people can easily interpret that wisdom in the light of the Gospel. Therefore this article will contribute a thought on how to build a sketch of Glocal theology.
\end{abstract}

Keywords: Sketch, Glocal, Theology.

\begin{abstract}
Abstraksi: Glocal Theology adalah model teologi yang ada di zaman post modernisme yang menekankan pada teologi konteks budaya setempat. Artinya memiliki penekanan pada usaha perjumpaan tradisi gereja dan tema-tema Kristiani dengan kenyataan hidup masyarakat disekitarnya. Berteologi secara sederhana itu senantiasa memahami sumber lokal yang terdiri dari ritual lokal, bahasa sehari-hari, lagu daerah, peribahasa dan bangunan seni. Dengan menggunakan unsur-unsur ini berarti seorang teolog berteologi secara kontekstual. Teolog itu hadir dan tinggal dengan orang-orang serta mendengarkan suara mereka. Dalam hal ini teologi sederhana itu berusaha menghargai dan menggunakan kebijaksaan yang ada pada budaya lokal, sehingga orang-orang lokal dapat dengan mudah memaknai kebijaksanaan itu dalam terang Injil. Oleh karena itu artikel ini akan memberikan sebuah kontribusi pemikiran bagaimana membangun sketsa Glocal theology.
\end{abstract}

Kata Kunci: Sketsa, Glocal, Teologi.

\section{PENDAHULUAN}

Sketsa glocal theology adalah sebuah rumusan yang berusaha mengangkat budaya-budaya lokal yang dapat dijadikan sebagai sarana mewartakan kabar baik atau sebagai sarana mewartakan injil kerajaan Allah. Penekanan sketsa glocal theology adalah mempertemukan Injil dengan budaya-budaya lokal. Sebenarnya sudah banyak artikel yang berusaha mengangkat budaya-budaya lokal seperti teologi inkulturasi. Bahkan sebelum istilah inkulturasi ada juga yang memakai istilah teologi adaptasi. Bagi Robert Schreiter Teologi Lokal, teologi inkulturasi, 
teologi kontekstual, pempribumian adalah sinonim saja, sebuah label yang bervariasi dari satu fakta dan aktifitas imaniah yang satu dan sama. ${ }^{1}$ Oleh karena itu tulisan ini secara khusus membahas sketsa glocal theology dalam lingkup yang lebih sempit agar pembahasan mencapai sasaran.

Latar belakang lahirnya glocal theology ini dikarenakan para teologi lokal menganggap bahwa untuk lebih mudah memahami injil harus lewat budaya lokal. Inilah sebabnya sebagian para teolog Amerika, Afrika, dan Asia menganggap teologi yang ada sekarang ini dipikirkan sebagai warisan kolonialisme Eropa. ${ }^{2}$

Selain faktor di atas, lahirnya glocal theology juga disebabkan karena faktor eksternal dan internal. Faktor eksternal yaitu; Pertama, Adanya ketidakpuasan di dunia pertama maupun dunia ketiga mengenai teologi klasik. Di dunia pertama, teologi klasik dianggap sudah tidak sesuai dengan pengalaman masa kini. Banyak pendekatan berteologi yang berkembang dengan menggunakan pendekatan ilmu-ilmu kontemporer. Di asia-Afrika, Amerika Latin, teologi tradisional juga ditolak karena teologi ini tidak sesuai dengan pola-pola budaya dan bentuk-bentuk pemikiran mereka. Kedua, Para Teolog lokal menganggap bahwa teologi klasik bersifat menindas. seperti yang dirasakan oleh orang-orang kulit hitam di Amerika selatan yang mengalami rasialisme dalam pola jawaban teologis yang tradisional di kebanyakan kalangan Kristen. ${ }^{3}$ Ketiga, Orang-orang miskin yang terpinggirkan di Amerika Latin. Keempat, Teologi klasik Barat yang menekankan keselamatan individual dan moralitas sering mengacaukan kebudayaan-kebudayaan yang hanya mengakui individu dalam konteks group.

${ }_{1}^{1}$ Robert J. Schreiter, Rancang Bangun Glocal Theology (Jakarta: BPK Gunung Mulia, 1993), 5.

2 Gerhard Sauter, Protestant Theology at The Crossroads: How to face The Crucial Tasks for Theology in The Twenty-First Century (Grand Rapids: Eerdmans Publishing, 2007), 102.

${ }^{3}$ Schreiter, Rancang Bangun Glocal Theology, 3. 
Kelima, Teologi tradisional juga menekankan superioritas pria yang berakibat pada pemikiran yang menyimpang tentang Allah, bahasa liturgi, dan peranan wanita dalam pelayanan. Keenam, Banyak orang yang terjun dalam pelayanan menemukan bahwa teologi yang telah mereka pelajari tidaklah memadai bagi persoalan-persoalan yang mereka hadapi dalam pekerjaan mereka. ${ }^{4}$ Ketujuh, Identitas yang berkembang dari gereja-gereja lokal sedang menuntut perkembangan glocal theology misalnya penggunaan budaya lokal dalam beribadah. Kedelapan, Pemahaman tentang kebudayaan didukung oleh tersedianya ilmu-ilmu sosial kontemporer.

Faktor Internal yang melatar belakangi glocal theology yakni: sifat keKistenan yang inkarnasional, sifat realitas yang sakramental, sifat pernyataan Allah yang inter-personal (Penyataan Allah adalah tawaran diri Allah kepada semua orang pria dan wanita, melalui tindakan-tindakan konkret dan simbolsimbol di dalam sejarah dan di dalam kehidupan sehari-hari para individu).

Hal yang sama dikatakan oleh William A. Dyrness dan Veli Karkkainen yang dikutip oleh Jan. Aritonang teologi lokal dilakukan karena banyak orang diberbagai wilayah di dunia telah menyadari bahwa mereka telah menerima teologi-teologi dari gereja-gereja dan misionari-misionari Eropa dan Amerika atau dari buku-buku teologi Eropa dan Amerika yang hampir tidak ada koneksinya dengan pengalaman dan situasi lokal. Teologi lokal telah dihasilkan dari kesadaran bahwa teologi tidak hanya berakar pada cerita-cerita Alkitab, melainkan juga melibatkan berbagai realitas konkret di berbagai lokal di mana

${ }^{4}$ Schreiter, 9 
orang Kristen hadir. ${ }^{5}$ Inti dari semuanya ini adalah ketidakpuasan dengan teologi klasik yang di dominasi oleh teologi barat yang tidak dapat menjawab persoalan yang dihadapi masa kini, dan Juga ada usaha menggunakan budaya-budaya lokal untuk menjadi sarana berteologi.

\section{METODOLOGI}

Metodologi yang digunakan dalam penelitian ini adalah pendekatan kualitatif. Penelitian kualitatif adalah berusaha memahami fenomena tentang apa yang dialami oleh subjek penelitian seperti perilaku, persepsi, motivasi dan tindakan, dan lain sebagainya yang diseskripsikan dalam bentuk kata-kata dan bahasa. ${ }^{6}$ Sumber data diambil dari berbagai literatur yang berkaitan dengan topik ini, sedangkan teknik pengumpulan data, dilakukan melalui wawancara dan pengamatan-pengamatan terhadap fakta-fakta atau fenomena-fenomena yang ada dalam budaya-budaya setempat. Teknik pengumpulan data juga dilakukan melalui metode Interaksi dialektis. Model ini menekankan interaksi yang dinamis antara teks dan konteks. Teks yang dimaksud adalah kebenaran Alkitab sedangkan konteks yang dimaksud adalah budaya-budaya yang dapat dijadikan sebagai sarana pemberitaan Injil. Konsep ini didukung oleh pemahaman yang kuat bahwa kebudayaan juga membawa perubahan. Tidak hanya Kekristenan yang membawa perubahan bagi konteks, tetapi konteks juga memberi perubahan bagi Kekristenan. ${ }^{7}$ Contohnya dalam teologi kebudayaan memberi warna baru bagi teologi dalam usahanya menghadirkan Kekristenan di tengah konteks yang ada, Yang perlu diperhatikan dalam berinteraksi ada dialog, dan dalam dialog tersebut

5 Jan S. Aritonang, Bahan Kuliah Teologi-Teologi Kontemporer (Batu: Institut Injil Indonesia, 2015), 55.

${ }^{6}$ Lexy J. Moleong, Metodologi Penelitian Kualitatif (Bandung: Remaja Rosda Karya, 2017), 6.

7 Yakub Tomatala, Teologi Kontekstual: Suatu Pengantar (Malang: Gandum Mas, 1993), 2. 
saling berbagi konsep nilai, kebiasaan, pola pikir, ide-ide. serta ada keterbukaan dan saling menghargai antara Injil, Gereja dan budaya.

\section{HASIL}

Prinsip Sketsa glocal theology adalah "budaya sarana berteologi”. Karna budaya memperlihatkan bahwa Kristus, Injil, kabar keselamatan yang disampaikan gereja sudah ada dalam budaya. Kristus ada di dalam budaya sebagai yang dijanjikan, yang masih akan datang. Seluruh perangkat budaya dapat dilihat sebagai nubuat tentang kedatangan Kristus dan keselamatan. Budaya bukan sesuatu yang tanpa makna, budaya dikaruniakan Tuhan dalam rangka tujuan yang ia kehendaki. ${ }^{8}$ Lebih lanjut Timo menjelaskan tidak ada alasan untuk menolak dan mengutuk budaya. Budaya harus dipelajari, dipahami dan dicintai. Seorang pemberita firman haruslah seorang pecinta budaya. Tanpa budaya, firman Tidak memiliki jalan masuk (point of contact) ke dalam hati manusia. Sebaliknya, tanpa firman budaya kehilangan tujuan dan makna yang sebenarnya. ${ }^{9}$ Apa yang dikatakan Timo menunjukkan bahwa budaya sangat penting dalam berteologi. Dengan demikian iman Kristen tidak perlu anti tehadap budaya, sebaliknya iman Kristen harus dapat menafsirkan budaya tersebut dengan baik dalam terang penafsiran Firman Tuhan yang benar. ${ }^{10}$

Kebudayaan adalah modal untuk merekonstruksi glocal theology bagi gereja. Nilai-nilai di dalamnya adalah kekayaan luar biasa yang dapat dipergunakan untuk dapat mengkomunikasikan berita kabar baik tentang Kristus. Dalam upaya membangun sketsa glocal theology harus memperhatikan kekayaan

8 Eben Nuban Timo, Pemberita Firman Pencipta Budaya (Jakarta: BPK Gunung Mulia, 2005), 79.

9 Timo, 80.

10 James A. Lola, "Iman Kristen Dan Budaya Popular," Visio Dei: Jurnal Teologi Kristen, 2019, 10121, https://doi.org/10.35909/visiodei.v1i1.7. 
budaya-budaya yang ada di lokal tersebut. Karena Budaya adalah suatu bagian dari kehidupan manusia, dan manusia yang berbudaya adalah manusia yang menghargai sesamanya. Yesus Kristus juga demikian Dia adalah pribadi yang tidak pernah terlepas dari ranah budaya di mana Dia hidup dan berkarya.

Bentuk kebudayaan lokal yang dimaksud keseluruhan ide, gagasan, perasaan nilai, norma dan aturan, segala aktifitas manusia di dalam Lingkungannya dan keseluruhan kerja manusia. ${ }^{11}$ Ketiga bentuk budaya di atas menyangkut sistem nilai, norma dan sistem sosial dan prilaku seperti tata krama dan nilai kepantasan dalam hubungan. Yang tidak kalah penting adalah hasil karya manusia seperti bangunan, tarian, lagu dan lain sebagainya. Bentuk-bentuk kebudayaan ini bagi glocal theology sangat penting karena kebudayaan menjadi sarana yang efektif dalam mewartakan kabar keselamatan.

Untuk menjelaskan bahwa kebudayaan menjadi sarana yang efektif dalam mewartakan keselamatan harus melalui interaksi. Dalam interaksi ada dialog, dan dalam dialog tersebut saling berbagi konsep nilai, kebiasaan, pola pikir, ide-ide. serta ada keterbukaan dan saling menghargai antara Injil, Gereja dan budaya. Dengan demikian Gereja membuka diri terhadap kebudayaan serta menghargainya. Demikian juga dengan budaya, membuka diri dan menghargai nilai-nilai yang diterapkan dalam gereja. Misalnya "ulos" pada budaya batak. Glocal theology harus melihat "ulos" dalam tiga aspek yakni aspek Injil, aspek sosial, dan aspek antropologi. Setelah itu menemukan titik temu tanpa mengorbankan prinsip Alkitab. Dengan menemukan titik temu, glocal theology mempublikasikan apa yang menjadi nilai yang bisa diterima oleh ketiganya

11 Koentjaraningrat, Kebudayaan, Mentalitas dan Pembangunan (Jakarta: Gramedia, 1995), 5-6. 
melalui seminar, dan kegiatan-kegiatan dialog lainnya. Nilai-nilai budaya setempat inilah yang bisa dipakai salah satu teolog lokal mengabarkan kabar sukacita.

Menurut Tom Jacobs dalam usaha memahami tradisi ini perlu keahlian menangkap khazanah pemahaman religius dan iman yang ada di dalamnya, sebab pemahaman ini memberi arah bagi refleksi teologi yang kreatif. ${ }^{12}$ Tom kembali menekankan bahwa faktor yang menentukan selain keahlian oleh teolog lokal adalah dialog antara teologi dan ilmu-ilmu lain dan partisipasi obesrvasi. ${ }^{13}$ Karena itu teolog lokal harus ahli dan kreatif agar kabar sukacita tersampaikan.

Tujuan pemakaian metode ini untuk mempertemukan Injil, Gereja dan Budaya. Pertemuan itu terjadi melalui interaksi dialektis. Interaksi yang dimaksudkan itu dibangun dalam proses yang sistematis. Proses itu dimulai dari glocal theology yang ditemukan dalam situasi konkret, dengan meneliti dan merumuskan kebudayaan lokal yang ditemukan, kemudian merumuskan kebudayaan itu yang relevan dengan refleksi teologis, diteliti dalam tradisi Kristiani, dan tradisi itu dilihat sebagai suatu rangkaian glocal theology.

Melalui metode ini glocal theology memberi ruang dialog dengan teologiteologi yang lain. Proses dialog bukan dalam rangka menyalahkan dan atau membenarkan teologi lain dalam rangka mencari keberpihakan, tetapi lebih dalam rangka masing-masing teologi menemukan titik signifikansinya, untuk selanjutnya bisa berkembang bersama-sama. Peran teolog lokal sangat penting. karena itu perlu mendapat ketrampilan, seni berdialog sekaligus berteologi yang semakin

12 Tom Jacobs, Teologi dan Praksis Komunitas Postmoderen, Teologi Yang Ekklesial Dan Kultural (Yogyakarta: Kanisius, 1994), 62.

13 Jacobs, 62-63. 
memampukan ia mencintai Tubuh Kristus di dunia (gereja), sekaligus pergumulan masyarakat dan budayanya.

Kelebihan glocal theology adalah mau menjadi suatu interaksi dialektis antara Injil, Gereja dan Budaya. ${ }^{14}$ Tujuannya untuk mempertemukan Injil, Gereja dan Budaya. Pertemuan itu terjadi melalui interaksi dialektis. Interaksi yang dimaksudkan itu dibangun dalam proses yang sistematis. Proses itu dimulai dari glocal theology yang ditemukan dalam situasi konkret, dengan meneliti dan merumuskan kebudayaan lokal yang ditemukan, kemudian merumuskan kebudayaan itu yang relevan dengan refleksi teologis, diteliti dalam tradisi Kristiani, dan tradisi itu dilihat sebagai suatu rangkaian glocal theology.

\section{PEMBAHASAN}

Berteologi lokal merupakan panggilan untuk menggunakan nilai-nilai dasar yang ada di suatu daerah sebagai sarana untuk mewartakan kabar keselamatan. Nilai-nilai itu ditemukan dan dihidupi oleh orang-orang yang ada di daerah berupa bahasa, kesenian dan kebiasaan atau adat. Dari orang-orang itulah, seorang teolog dapat masuk untuk membawa nilai-nilai Injil yang hendak diwartakan. Akan tetapi, perlu diperhatikan bahwa relasi yang dibangun dengan orang-orang itu haruslah senantiasa didasari oleh hubungan atau komunikasi dengan Allah. Dengan demikian, akan tumbuh keselarasan atau kesinambungan yang selalu memberi arah dalam menghidupi nilai-nilai dasar yang sudah dalam terang Injil.

Dalam berteolog secara lokal, seorang teolog tidak akan pernah lepas dari pengalaman hidup sehari-hari yang dijalani oleh orang-orang yang ada

\footnotetext{
14 Jacobs, 58.
} 
disekitarnya. Pola perilaku dan tindakan sehari-hari menjadi bagian yang perlu diperhatikan oleh seorang teolog, sehingga ia mampu berbicara dan bersaksi sesuai dengan realitas yang ada. Seorang teolog, perlu terlibat secara langsung dalam bertindak atas nilai-nilai dasar yang dimiliki oleh orang-orang disekitarnya. Keterlibatan secara langsung dalam kehidupan sehari-hari dapat menjadi pintu masuk bagi seorang teolog untuk memahami dan memaknai nilai dasar yang ada. Dengan mengetahui dan memaknai nilai itu secara mendalam, teolog dapat dengan mudah menyampaikan isi pewartaannya menggunakan nilai-nilai yang sudah ada. Dalam hal ini teolog dapat digambarkan sebagai koki desa yang memasak dengan bahan-bahan yang sudah ada di desa tersebut.

Untuk memahami lebih dalam pokok pemikiran glocal theology, di bawah ini penulis akan menjelaskan defenisi glocal theology, dasar glocal theology, prinsip glocal theology dan model-model glocal theology.

\section{Defenisi Glocal Theology}

Glocal theology adalah model teologi yang ada di zaman postmodernisme yang menekankan pada teologi konteks budaya setempat. Artinya memiliki penekanan pada usaha perjumpaan tradisi gereja dan tema-tema Kristiani dengan kenyataan hidup masyarakat disekitarnya. Menurut Tomatala glocal theology adalah istilah yang dipakai oleh para teolog Katolik Roma dan sebagian teolog protestan. Alasan penggunaan istilah ini ialah beranggapan bahwa istilah ini lebih menggambarkan kepekaan terhadap konteks, serta mencegah penggunaan neologisme yang tidak perlu. ${ }^{15}$ Dengan demikian glocal theology dapat didefenisikan "sebagai interaksi dinamis antara injil, gereja dan budaya. Interaksi

15 Tomatala, Teologi Kontekstual: Suatu Pengantar, 5. 
dinamis itu dipandang sebagai interaksi dialektis, bergerak ke depan dan ke belakang di antara berbagai aspek injil, gereja dan budaya.

\section{Dasar Glocal Theology}

Gambaran mengenai berteologi secara lokal itu tampak dalam diri Yesus Kritus. Ia memulai pewartaan-Nya dengan nilai-nilai dasar yang dihidupi oleh masyarakat Yahudi. Dalam praktek hidup sehari-hari Yesus turut ambil bagian dalam aktivitas orang Yahudi dan memulai pembaruan-Nya dari nilai dasar yang ada pada budaya itu sendiri. Yesus masuk dan mengalami budaya Yahudi itu secara mendalam, kemudian membaharui pemahaman orang Yahudi yang tidak sesuai dengan isi dari nilai budaya. Karya dan pewartaan-Nya ditandai dengan pelayanan kepada orang-orang 'kecil' yang kadang-kadang tidak diperhatikan oleh orang Yahudi. Yesus menyembuhkan, mengampuni dan mengajar orangorang yang tidak diperhatikan itu sebagai tempat berteologi.

Banyak referensi Alkitab yang dapat kita tunjukkan. Yesus misalnya tetap merayakan hari sabat, tata sosial bermasyarakat orang Yahudi. Markus 2: 27 menyatakan hari sabat diadakan untuk manusia bukan manusia untuk hari sabat. Yesus tetap setia pada aturan-aturan bangsa-Nya, tetapi waktu Ia ada di luar Israel seorang datang kepada-Nya memohon perlindungan, Ia melayani permintaan -Nya (Mrk. 7: 24-30). Yesus tidak meniadakan atau membatalkan adat istiadat bangsaNya, Ia menyempurnakan, Ia memperbaiki pemahaman yang keliru terhadap hukum hari sabat. Ia memberi pengertian yang benar terhadap siapa sesama kita (Luk, 10:25-27). ${ }^{16}$

16 Timo, Pemberita Firman Pencipta Budaya, 81. 
Yang dilakukan Yesus ini merupakan bentuk pembaharuan-Nya untuk membantu orang Yahudi dalam menemukan nilai dasar dari budaya atau tradisi yang ada pada mereka. Dari tindakan Yesus ini, seorang dapat bercermin tentang bagaimana berteologi secara lokal. Kuncinya ialah perjumpaan dengan budaya yang sudah ada, kemudian berteologi dari budaya itu dengan memberi makna atau nilai dasar yang dikandung oleh budaya itu.

Dari cara Yesus berteologi secara lokal, ada suatu hal yang tampak ialah pemahaman yang mendalam tentang konteks dari nilai-nilai yang dianut oleh orang Yahudi. Pemahaman yang mendalam itu menjadi modal utama dalam memberi isi secara baru pada nilai yang sudah ada. Melalui pemahaman yang mendalam itu, nilai dasar dari suatu budaya dapat dengan mudah ditemukan. Oleh karena itu, berteologi secara lokal menuntut pemahaman yang mendalam tentang nilai suatu budaya sebelum digunakan sebagai sarana berteologi.

Sebagai seorang teolog, keinginan untuk mencontoh bentuk pelayanan Yesus tidak akan terlepas dari Kitab Suci. Dari Kitab Suci seseorang dapat melihat bentuk pelayanan Yesus dan hubungan berupa nilai dasar yang sesuai dengan konteks saat ini. Untuk dapat melihat nilai dasar itu diperlukan pemahaman mendalam dari Kitab Suci. Pengetahuan mendalam atas Kitab Suci akan memberi arah apabila dibaca dalam konteksnya. Dalam hal ini yang diperjuangkan ialah berteologi secara baik dan benar. Dengan memahami Kitab Suci secara mendalam, usaha untuk membangun glocal theology tetap berada dalam terang Injil. Pada akhirnya, nilai-nilai dasar dari suatu budaya lokal itu dapat berkembang sebagai pedoman hidup. 


\section{Tonggak Glocal Theology}

Upaya membangun glocal theology ada tiga tiang tonggak yang harus diperhatikan dengan sungguh-sungguh. Ketiga tiang tonggak itu berinteraksi secara dinamis dan dialektis (saling memberi pengaruh secara timbal balik) sepanjang sejarah. Adapun ketiga tiang tonggak itu ialah injil, gereja, dan kebudayaan. ${ }^{17}$ Injil mengendap di dalam gereja, bahkan gereja itu hidup dari dan oleh Injil. Lalu gereja, di dalam karya pewartaan misionernya, berjumpa dengan pelbagai macam kebudayaan baru dimana saja Injil itu diwartakan oleh gereja.

Ketiganya selalu berinteraksi secara dinamik. Dan interaksi dinamik itu selalu bersifat dialetik, artinya saling pengaruh pengaruh secara timbal bailk secara tidak terhindarkan diantara pelbagai aspek di dalam ketiga tiang tonggak itu sendiri

\section{Arah Glocal Theology}

Glocal theology lebih sering ditujukan kepada gereja lokal dan gereja lebih luas. Semuanya menekankan konsolidasi diri komunitas Kristen. Glocal theology juga ditujukan masyarakat khususnya bila itu berupa persoalan bagaimana menghadapi masalah-masalah sosial dan masalah-masalah budaya. Keprihatinan glocal theology bukan hanya menyangkut perbedaan yang mungkin muncul, tetapi juga terhadap keterlibatan lebih banyak orang Kristen dalam usaha refleksi teologis. Keterlibatan demikian banyak mendukung terhadap apa yang membuat sebuah teologi menjadi glocal theology, walaupun hasilnya tampak serupa dengan dengan apa yang ada ditempat-tempat lain.

\footnotetext{
17 Schreiter, Rancang Bangun Glocal Theology, 22.
} 


\section{Model Glocal Theology}

Membangun sketsa glocal theology yang benar harus menemukan model yang telah dipraktekan di dalam Alkitab. Model ini mempermudah seorang yang berteologi untuk menjangkau orang-orang yang memiliki budaya lokal antara lain:

\section{Kontekstualisasi Inkarnasi}

Model kontekstualisasi Inkarnasi adalah model glocal theology yang berusaha menginterprestasikan Alkitab ke dalam konteks lokal dengan tidak mengorbankan prinsip Alkitab yang bertentangan dengan budaya. Kontekstualisasi inkarnasi dapat ditemukan di dalam Filipi 2: 6-7. Ayat ini tidak hanya menekankan tentang kerendahan Hati Allah tetapi juga menjelaskan tentang kontekstuaslisasi. Prinsip inkarnasi dalam konteks glocal theology adalah menjadi sama seperti manusia artinya menyesuaikan diri dengan konteks budaya lokal. Tetapi ada hal yang tidak sama yaitu Yesus tidak menjadi berdosa. Ini yang disebut dengan kontekstualisasi inkarnasi.

Glocal theology memahami bahwa kontekstualisasi inkarnasi menjadi sebuah usaha interprestasi Alkitab secara benar dan pada saat yang bersamaan, mengkomunikasikan pesan-pesan kekristenan secara efektif dalam sebuah konteks budaya, sekaligus menjadi upaya menghargai pesan kekristenan melalui dan di dalam budaya tersebut. ${ }^{18}$ Kontekstualisasi inkarnasi memasukan pesan-pesan kekristenan ke dalam suatu bentuk kebudayaan bukan Kristen, serta melibatkan seluruh aspek hidup manusia yang ada di dalamnnya seperti seni budaya tradisional, spiritualitas dan lain sebagainya.

18 David J. Hesselgrave dan Edward Rommen, Kontekstualisasi: Makna Metode dan Model (Jakarta: BPK Gunung Mulia, 2012), 77-78. 
Konsep ini menjadi salah satu sarana yang baik dalam mengabarkan kabar sukacita. Menurut Theodoros Kobong Kontekstualisasi atau inkulturasi merupakan proses atau metode yaitu metode yang ditempuh dalam implementasi rencana Allah dalam inkarnasi, yang pada gilirannya terikat pada konteks dan dengan demikian berlangsung dalam kebudayaan tertentu serta tidak mutlak sama dimana-mana. ${ }^{19}$ Artinya seorang teolog lokal harus menyesuaikan diri dengan budaya lokal tersebut, hanya diingat tidak boleh mengorbankan prinsip Alkitab. Maksudnya sepanjang budaya tidak bertentang dengan Alkitab glocal theology harus menggunakan budaya tersebut. Tujuan dari bentuk inkarnasi adalah agar manusia dapat memahaminya.

Model kontekstualisi inkarnasi adalah perjumpaan, tetapi bukan sekedar pertemuan, melainkan perjumpaan dalam pengertian ada kesediaan untuk saling menerima dan memperhatikan suara dari pihak lain. Perjumpaan tidak hanya dipahami konfrontatif, tetapi melalui proses dinamis tersebut terjadi sebuah penerimaan tentang hal-hal yang berbeda dari yang lain ke dalam dirinya (konteks budaya) untuk didialogkan sehingga menghasilkan sebuah kesadaran baru sebagai bukti hasil penerimaan tersebut. Tidak semua diterima, tetapi ada hal-hal yang tidak berlalu begitu saja sebab keberadaan yang lain tidak dipahami sebagai harus ditolak melainkan sebagai partner untuk mengembangkan khasanah berteologi yaitu ketika teologi bertemu dengan kompleksitas budaya, sehingga banyak sisi dan sudut yang dipertimbangkan dalam diskursus tersebut. ${ }^{20}$ Artinya dalam

19 Theodorus Kobong, Injil dan Tongkonan: Inkarnasi, Kontekstualisasi, Transformasi (Jakarta: BPK Gunung Mulia, 2008), 220.

20 Yusak Tridarmanto, Perjumpaan Interaktif Antara Teologi Dan Budaya: Kajian Tentang Pemahaman dan Persepsi Mengenai Teologi Interkultural di Aras Akademik dan Gerejawi (Yogyakarta: Yayasan Taman Pustaka Kristen Indonesia, 2018), 16. 
berkontekstualisi harus memiliki yakni sikap menerima apa yang sesuai dengan Alkitab, menolak apa yang tidak sesuai dengan Alkitab.

Prinsip-prinsip umum kontekstualisasi inkarnasi. ${ }^{21}$ Pertama, menjaga keseimbangan. Kuncinya adalah memelihara semacam keseimbangan. Jika tidak, maka kontekstualisasi akan menghadapi sejumlah masalah, baik yang bersifat teologis maupun praktis. Keseimbangan yang dimaksud sebagai berikut (1) kontinuitas - diskontinuitas. Kontinuitas dilakukan terhadap kebenaran mutlak dan kebudayaan yang masih relevan dengan masyarakat setempat. Dan, diskontinuitas dilakukan terhadap segala bentuk kontaminasi religi maupun tradisi. (2) Missiologis - teologis. Kontekstualisasi menghadapi pergumulan ganda, yaitu bagaimana Injil bisa diterima (Komitmen Missiologis) dan bagaimana Injil dijaga kemurniannya (Komitmen Teologis). Tetapi, sepertinya adanya kecenderungan berat sebelah, kehilangan keseimbangan. Kadang lebih cenderung ke komitmen teologis, kadang sebaliknya. Menekankan salah satu berarti hanya memenuhi salah satu panggilan Tuhan. Komitmen missiologis memenuhi Amanat Agung (Matius 28: 19-20), sedangkan komitmen teologis memenuhi Ibadah Agung (Ulangan 5: 7-10). Tekanan para misiologis saja melahirkan kompromis, sinkritis yang berakibat pada pelanggaran terhadap Ibadah Agung. Sebaliknya, tekanan pada teologis saja menyebabkan statis karena kontekstualisasi dan akibatnya tidak melaksanakan Amanat Agung sepenuhnya. (3) Perbesaran - persamaan. Sebagai komunitas baru, orang-orang Kristen memunyai cara hidup baru yang berpusat pada "Worldview" (Pandangannya) yang baru. Oleh orang-orang pada umumnya, kekristenan dilihat sebagai "cara hidup 21 Imanuel Sukardi, "'Prinsip-Prinsip Kontekstualisasi'," www.misi.sabda.org, E-Misi, 2012, http:// misi. sabda. org / prinsip-prinsip-kontekstualisasi. 
yang baru". Dengan kata lain, keKristenan menghapus persamaan dan melahirkan perbedaan antara non-Kristen dan Kristen. Perbedaan semacam itu perlu dipertahankan secara radikal sekalipun untuk kepentingan dua hal. Pertama, demi kemurnian Injil, dan yang kedua untuk memberi pilihan lain kepada individu nonKristen. Jika tidak ada perbedaan, maka tidak ada alasan bagi mereka untuk menjadi orang Kristen. Logikanya akan berkata, "Kalau ternyata sama, mengapa harus menjadi orang Kristen?" Dengan demikian, jelas bahwa perbedaan akan memberi pilihan dan tawaran baru bagi mereka yang belum Kristen. (4) Kreatif persuasif. Dalam dunia penginjilan, kontekstualisasi bukanlah tujuan, melainkan cara yang dipakai untuk mencapai tujuan. Tujuan kontekstualisasi bukan supaya ada kontekstualisasi, melainkan supaya ada hasil penginjilan yang lebih besar. Agar hal itu terjadi, maka diperlukan kreativitas yang persuasif. Kreatif -persuasif bagaikan dua sisi mata uang logam yang tidak bisa ditiadakan salah satunya. Kreatif berkenaan dengan pendekatan, sedangkan persuasif berkenaan dengan pemberitaan. Pendekatan tanpa pemberitaan bukan berarti penginjilan. Sedangkan pemberitaan tanpa pendekatan berarti sia-sia. Oleh sebab itu, kontekstualisasi yang menjaga keseimbangan kedua hal tersebut akan lebih banyak memberi harapan.

Kedua, Menjaga kesinambungan. Tujuan penginjilan kontekstual adalah pendirian gereja yang kontekstual. Sedangkan tujuan pendirian gereja yang kontekstual adalah penginjilan yang kontekstual dan begitulah seterusnya. Kurang dari itu bisa disebut ketidakseimbangan. Penginjilan kontekstual yang tidak menghasilkan gereja yang kontekstual, tidak akan melahirkan gereja baru yang kontekstual. Jika tidak ada gereja baru yang kontekstual, maka tidak akan ada 
penginjilan yang kontekstual. Sebab, jenis gereja baru yang ada ditentukan oleh jenis gereja lama yang sudah ada. (1) Menguji keabsahan. Pertama, apakah kata Alkitab? Maksudnya untuk menghindari sinkritisme maupun teosentrisme, dan tetap pada posisi Kristusentris. Inilah dasar penilaian pertama. Kedua, apa kata kelompok sasaran? Sebagai kelompok sasaran, penilaian dan anggapan mereka terhadap suatu pendekatan harus benar-benar diperhatikan dan dipertimbangkan. Sebab, faktor inilah yang menjadi kunci penentu, apakah akhirnya mereka menerima atau menolak berita yang disampaikan. Ketiga, apa kata diri sendiri? Ini juga unsur yang tidak kalah penting untuk dipertimbangkan. Sebagai pemberita, apakah pendekatan yang dipakai telah melanggar hati nurani sendiri? Jika jawabannya "Ya", maka Anda perlu mengubah pendekatan. (2) Mengantisipasi perubahan. Kontekstualisasi memiliki dua masalah sekaligus dari dalam dan dari luar. Dari dalam disebut sinkritisme, sedang dari luar disebut modernisasi. Modernisasi adalah suatu proses perubahan yang diusahakan guna mencapai kebudayaan yang lebih modern. Menurut definisi ini, modernisasi boleh dikatakan merupakan ancaman kontekstualisasi di masa yang akan datang. Modernisasi bisa membuat apa yang telah dirumuskan oleh kontekstualisasi sekarang menjadi tidak relevan di masa yang akan datang, dengan adanya transformasi yang dimotori oleh modernisasi. Ciri utama modernisasi bukanlah gaya hidup yang kebaratbaratan, melainkan rasionalisasi. Tegasnya, modernisasi adalah pergeseran dari yang bersifat irasional menuju kepada hal yang bersifat rasional.

Prinsip-Prinsip Khusus Kontekstualisasi Inkarnasi : Pertama, Menilai unsur-unsur budaya : (i) Unsur-Unsur Budaya yang Netral. Berbicara tentang unsur-unsur budaya yang tidak diajarkan oleh Alkitab dan juga tidak bertentangan 
dengan Alkitab itu sendiri. (ii) Unsur-unsur Budaya yang Bertentangan dengan Alkitab. Kebudayaan biasanya bercampur dengan budaya lokal. Kebudayaan semacam itulah yang sering kali bertentangan dengan Alkitab. Di sinilah pentingnya mempelajari setiap unsur budaya masyarakat yang menjadi kelompok sasaran. Kedua, Mengenal kelompok sasaran. Melalui pendekatan multi konteks misalnya: (1) Pendekatan melalui pintu agama dengan cara mencari dan mengamati berbagai titik celah keagamaan, yang dapat menjadi peluang bagi Injil untuk dikontekstualisasikan. (2) Pendekatan melalui budaya (3), Pendekatan melalui filsafat. Setiap orang adalah filsuf dan akan hidup selalu dengan filsafatnya. Oleh sebab itu, perlu pendekatan yang relevan terhadap filsafat hidup orang yang disapa.

\section{Model Akomodasi}

Akomodasi adalah sikap menghargai dan terbuka terhadap kebudayaan asli. $^{22}$ Sikap ini dinyatakan dalam bentuk kelakuan, perbuatan, dan perkataan baik dalam ranah ilmiah maupun praktis. Objek akomodasi adalah kehidupan budaya yang menyeluruh dari suatu bangsa, baik dari segi fisik, sosial. Dalam pendekatan ini terjadi sebuah pengambilalihan nilai-nilai budaya dan dipadukan dengan nilai-nilai Kristiani. Dengan demikian terdapat pandangan positif bagi Alkitab.

Karena glocal theology harus mulai dengan membuka budaya, dengan hati-hati untuk mendengarkan nilai-nilai utamanya, kebutuhan, minat arah dan lambang-lambangnya. Hanya dengan cara konfigurasi suatu budaya menjadi jelas, tanpa semata-mata menjawab para jenis-jenis kebutuhan lain yang tidak

22 Tomatala, Teologi Kontekstual: Suatu Pengantar, 2. 
pokok bagi budaya itu. Dibalik pendekatan ini yang diusulkan untuk memahami budaya-mendengarkan, mengembangkan deskripsi tebal, menemukan keseimbangan antara penghargaan akan budaya dan kebutuhan akan perubahan di dalam budaya tertelak suatu posisi teologi yang menjadi ciri khas banyak teologis lokal. Glocal theology sendiri tergantung pada usaha menemukan Kristus yang sudah aktif dalam budaya, ketimbang membawa Kristus ke budaya itu. Penghargaan yang besar terhadap budaya mempunyai dasar Kristologi. Ia bertumbuh dari keyakinan bahwa kegiatan penyelamatan Kristus yang sudah bangkit dalam menghadirkan Kerajaan Allah sudah berlansung sebelum kita tiba. Jadi model akomodasi ini menekankan kepada mendengar dan menghargai budaya lokal agar kabar sukacita bisa di wartakan.

\section{Budaya Merupakan Perwujudan Penciptaan Allah}

Budaya lokal itu dapat dikatakan sebagai suatu 'perwujudan' dari kelanjutan proses penciptaan Allah. Sebagai kelanjutan hal itu, tentu ada banyak hal yang dapat digunakan sebagai sarana pewartaan. Hal ini dapat ditemukan dalam Kisah Para Rasul 17: 22-28. Seorang pujangga zaman dahulu mengatakan bahwa di Atena orang lebih muda bertemu dengan seorang dewa dari pada seorang manusia. ${ }^{23}$ Paulus di sini sudah menggunakan dua sarana lokal untuk memberitakan injil yakni patung yang bertulisan Allah yang tidak di kenal dan pujangga-pujangga saat itu. Tidak hanya itu Paulus ditampilkan sebagai orang yang memanfaatkan pengertian-pengertian keagamaan dan kebudayaan yang ada dan tidak menyembahnya. Ini adalah sikap mengahargai dengan terkendali. ${ }^{24}$ Ini 
yang disebut dengan berteologi lokal. Paulus menjelaskan Allah yang benar dalam konteks budaya lokal saat itu. cara ini sangat efektif

Agar seorang teolog dapat masuk dalam nilai dasar dari budaya lokal, ia harus memahami situasi masyarakat karena disitulah tampak wajah dari budaya yang mengandung banyak nilai dasar. Situasi masyarakat itu dapat dilihat dari bahasa, tindakan dan perilaku sehari-hari. Situasi inilah yang perlu diberi perhatian secara serius, sehingga menghasilkan atau menampakkan nilai dasar yang terselubung dalam budaya lokal itu, sebagaimana yang dimaksudkan oleh Allah. Selain itu, dengan memberi perhatian serius pada bahasa, tindakan dan perilaku, seorang teolog akan memperlihatkan tanda bahwa ia sungguh menghargai budaya lokal yang ada.

Pemahaman akan suatu budaya lokal itu dapat dilakukan dengan memperhatikan tiga aspek, yaitu: aspek sosial, aspek sejarah dan aspek politik. Ketiga aspek ini perlu ditempatkan dalam konteks budaya lokal. Penempatan ketiga aspek ini dalam konteks membutuhkan disiplin ilmu lain, misalnya ilmu sosial. Adanya disiplin ilmu lain itu membuat analisa terhadap kebiasaan hidup masyarakat menjadi lebih mendalam. Disiplin ilmu lain membantu seorang teolog mengangkat situasi partikular yang mengandung nilai dasar dalam budaya lokal. Dalam hal ini seorang teolog menerapkan teologi sederhana yang memiliki tujuan, antara lain: menunjukkan kekayaan positif dan kebaikan dari konteks lokal; menantang konteks lokal dengan mengajak orang melihat dan masuk pada batasnya; menginspirasi orang dengan melihat visi yang tidak kelihatan dan mendengarkan seruan yang tidak didengarkan. 
Berteologi secara sederhana itu senantiasa memahami sumber lokal yang terdiri dari ritual lokal, bahasa sehari-hari, lagu daerah, peribahasa dan bangunan seni. Dengan menggunakan unsur-unsur ini berarti seorang teolog berteologi secara kontekstual. Teolog itu hadir dan tinggal dengan orang-orang serta mendengarkan suara mereka. Dalam hal ini teologi sederhana itu berusaha menghargai dan menggunakan kebijaksaan yang ada pada budaya lokal, sehingga orang-orang lokal dapat dengan mudah memaknai kebijaksanaan itu dalam terang Injil.

\section{KESIMPULAN}

Glocal theology merupakan jembatan penghubung antara Injil, gereja dan budaya. Melalui glocal theology nilai-nilai yang ada di dalam budaya lokal dapat dipakai untuk menjadi sarana mewartakan kabar sukacita. Model ini telah dipraktekan oleh Tuhan Yesus dan Rasul Paulus dalam mewartakan kabar keselamatan.

Prinsip glocal theology adalah menjadikan budaya sebagai salah satu sarana dalam berteologi dan dalam mewartakan kabar sukacita. Bagi glocal theology budaya lokal harus dihargai. Karna budaya mampu menyederhanakan pemberitaan Injil dan model ini sangat efektif.

Meski demikian glocal theology harus memperhatikan budaya-budaya yang bertentangan dengan Alkitab. Budaya yang bertentangan dengan alkitab tidak boleh dikompromikan melainkan dituntun kepada kebenaran. Budaya yang tidak bisa dikompromikan harus didiskusikan agar dapat dituntun kepada kebenaran yang Alkitabiah. 
Gereja hendaknya membuka diri dan memberikan perhatian serius terhadap budaya lokal, agar budaya yang baik dijadikan sebagai sarana mewartakan kabar sukacita seperti alat-alat musik, lagu-lagu daerah, bentuk gedung gereja, wayang, dan budaya lokal lainnya. Gereja harus menyadari glocal theology diakui telah tinggal dan bersemayam di tengah-tengah pergumulan umat, dalam hidup kesehariannya, dalam cerita rakyat dan cerita kehidupannya. Sehingga teologi kita sangat kontekstual.

\section{DAFTAR PUSTAKA}

Aritonang, Jan S. Bahan Kuliah Teologi-Teologi Kontemporer. Batu: Institut Injil Indonesia, 2015.

Browning, W.R.F. A Dictionary of the Bible. Jakarta: BPK Gunung Mulia, 2009.

Hesselgrave, David J., dan Edward Rommen. Kontekstualisasi: Makna Metode dan Model. Jakarta: BPK Gunung Mulia, 2012.

Jacobs, Tom. Teologi dan Praksis Komunitas Postmoderen, Teologi Yang Ekklesial Dan Kultural. Yogyakarta: Kanisius, 1994.

Kobong, Theodorus. Injil dan Tongkonan: Inkarnasi, Kontekstualisasi, Transformasi. Jakarta: BPK Gunung Mulia, 2008.

Koentjaraningrat. Kebudayaan, Mentalitas dan Pembangunan. Jakarta: Gramedia, 1995.

Lola, James A. "Iman Kristen Dan Budaya Popular." Visio Dei: Jurnal Teologi Kristen, 2019, 101-21. https://doi.org/10.35909/visiodei.v1i1.7.

Moleong, Lexy J. Metodologi Penelitian Kualitatif. Bandung: Remaja Rosda Karya, 2017.

Sauter, Gerhard. Protestant Theology at The Crossroads: How to face The Crucial Tasks for Theology in The Twenty-First Century. Grand Rapids: Eerdmans Publishing, 2007.

Schreiter, Robert J. Rancang Bangun Glocal Theology. Jakarta: BPK Gunung Mulia, 1993.

Spittler, Russell P. Allah Sang Bapa. Malang: Gandum Mas, t.t. 
Sukardi, Imanuel. “'Prinsip-Prinsip Kontekstualisasi'.” Www.misi.sabda.org. EMisi, 2012. http:// misi. sabda. org / prinsip-prinsip-kontekstualisasi.

Timo, Eben Nuban. Pemberita Firman Pencipta Budaya. Jakarta: BPK Gunung Mulia, 2005.

Tomatala, Yakub. Teologi Kontekstual: Suatu Pengantar. Malang: Gandum Mas, 1993.

Tridarmanto, Yusak. Perjumpaan Interaktif Antara Teologi Dan Budaya: Kajian Tentang Pemahaman dan Persepsi Mengenai Teologi Interkultural di Aras Akademik dan Gerejawi. Yogyakarta: Yayasan Taman Pustaka Kristen Indonesia, 2018. 